This item was submitted to Loughborough's Research Repository by the author.

Items in Figshare are protected by copyright, with all rights reserved, unless otherwise indicated.

\title{
Experimental validation of shear-mediated contributions to multiple scattering in concentrated random dispersions of spherical particles
}

\section{PLEASE CITE THE PUBLISHED VERSION}

https://doi.org/10.1121/1.4950499

\section{PUBLISHER}

(C) Acoustical Society of America

\section{VERSION}

AM (Accepted Manuscript)

\section{PUBLISHER STATEMENT}

This work is made available according to the conditions of the Creative Commons Attribution-NonCommercialNoDerivatives 4.0 International (CC BY-NC-ND 4.0) licence. Full details of this licence are available at: https://creativecommons.org/licenses/by-nc-nd/4.0/

\section{LICENCE}

CC BY-NC-ND 4.0

\section{REPOSITORY RECORD}

Pinfield, Valerie J., D. Michael Forrester, and Jinrui Huang. 2018. "Experimental Validation of Shear-mediated Contributions to Multiple Scattering in Concentrated Random Dispersions of Spherical Particles". figshare. https://hdl.handle.net/2134/27924. 


\title{
Experimental validation of shear-mediated contributions to multiple scattering in concentrated random dispersions of spherical particles
}

\author{
Valerie J Pinfield, D Michael Forrester, J Huang \\ Chemical Engineering Department, Loughborough University, UK
}

Multiple scattering models for ultrasound propagation in dispersions of spherical particles have conventionally included only multiple scattering of the compressional wave mode. Recent developments to these models by Luppé, Conoir and Norris (J Acoust Soc Am, 2012 (131) 1113) have incorporated the effects of mode conversions into the multiple scattering model; these arise from shear and thermal wave modes produced by scattering at each particle. In our recent work, we have reported the identification of the dominant contributions to effective attenuation in such dispersed systems for either solid or liquid particles, and have reported both analytical and numerical solutions for them. Here we present the key results for shear-mediated multiple scattering effects which are dominant in concentrated systems of small solid particles (sub-micrometer) in the mega-Hertz frequency range. We show experimental validation of the model predictions for silica particles in the size range $100 \mathrm{~nm}-1$ micrometer and 1-20 MHz using two different spectroscopy techniques, first, a pseudo-continuous wave spectrometer (the Malvern Ultrasizer), and secondly a pseudo-random binary sequence cross-correlation spectrometer (Digusonic DSX) suitable for in-line process monitoring. 